\title{
Pengaruh sanitasi lingkungan dan perilaku keluarga terhadap kejadian penyakit demam berdarah dengue (DBD) di Kecamatan Benai Kabupaten Kuantan Singingi
}

\author{
Retno Wulandari ${ }^{1}$, Rasoel Hamidy ${ }^{2}$, Bayhakki ${ }^{3}$ \\ ${ }^{1,2}$ Program Studi Magister Ilmu Lingkungan Program Pascasarjana Universitas Riau \\ ${ }^{3}$ Fakultas Keperawatan Universitas Riau \\ *Correspondent Email : ayi_wulandari@yahoo.com
}

Diterima: 12 Agustus 2021 | Disetujui: 30 Agustus 2021 | Diterbitkan: 31 Agustus 2021

\begin{abstract}
Dengue hemorrhagic fever is an infection caused by the dengue virus, the dengue virus is transmitted through the bite of the Aedes aegypti mosquito. The incidence of dengue hemorrhagic fever is influenced by various factors such as environmental sanitation, economy and behavior. This study aims to determine the effect of environmental sanitation and family behavior on the incidence of dengue hemorrhagic fever in Benai District, Kuantan Singingi Regency. This type of research is quantitative with cross sectional design. Data analysis used univariate, bivariate with chi square test and multivariate using binary logistic regression model parameter testing. The results showed that the variables of environmental sanitation and behavior in Benai District, Kuantan Singingi Regency were not optimal so that they were at risk of experiencing dengue fever. Environmental sanitation and behavior variables simultaneously and significantly influence the incidence of dengue hemorrhagic fever in Benai District, Kuantan Singingi Regency. This is related to the large amount of waste that is not properly managed around residents' homes and there are also clean water storage places that are not closed, this condition is due to the lack of public knowledge about the importance of maintaining environmental cleanliness and how to do 3M. Besides that, the attitude of the people who do not care about it also illustrates that the behavior of the people in the area is still lacking.

Keywords: Environmental Sanitation; Family Behavior; Dengue Hemorrhagic Fever
\end{abstract}

Demam Berdarah Dengue (DBD) merupakan penyakit demam akut disertai dengan manifestasi perdarahan bertendensi menimbulkan syok dan dapat menyebabkan kematian, umumnya menyerang pada anak < 15 Tahun, namun tidak tertutup kemungkinan menyerang orang dewasa. Tanda-tanda penyakit ini adalah demam mendadak 2 sampai dengan 7 hari tanpa penyebab yang jelas, lemah, lesu, gelisah, nyeri ulu hati, disertai tanda-tanda perdarahan dikulit (petechiae), lebam (echymosis) atau ruam (purpura). Kadang-kadang mimisan, berak darah, kesadaran menurun atau renjatan (shock) (Depkes RI, 2013).

Kejadian DBD dapat dipengaruhi oleh berbagai faktor seperti ekonomi, ekonomi yang rendah akan berisiko terhadap kejadian DBD. Selain ekonomi, kondisi lingkungan sangat mempengaruhi penyebaran nyamuk Ae. Aegypti di sekitar kita. Selain itu juga lingkungan biologik serta perilaku masyarakat yang masih cenderung belum optimal menerapkan pola hidup bersih dan sehat. Kondisi lingkungan biologi meliputi tingkat kelembaban, intensitas cahaya yang rendah, banyaknya naungan seperti pepohonan, adanya predator merupakan faktor yang sangat berpengaruh terhadap perkembangan spesies ini. Kondisi lingkungan fisik seperti letak dan karakteristik rumah, jenis kontainer atau tempat penampungan air, warna dinding rumah dan pengaturan perabotan di dalam rumah berpengaruh pada populasi nyamuk Ae. Aegypti. Perilaku masyarakat juga berpengaruh besar karena perilaku masyarakat dapat memberikan daya dukung lingkungan bagi perkembangan nyamuk. Kebiasaan hidup menjaga kebersihan dan kesehatan lingkungan seperti 3M+ (Menguras, Mengubur dan Menutup tempat penampungan air + Abate) sebagai upaya mencegah terjadinya wabah Demam Berdarah Dengue (DBD). Kebiasaan menggantung baju di rumah dan aktivitas masyarakat yang memberikan akibat naiknya daya dukung lingkungan terhadap perkembangan nyamuk Ae aegypti. Tinggi rendahnya populasi nyamuk Ae.aegypti. berpengaruh pada kejadian kasus DBD (WHO, 2009).

Angka kejadian DBD diprovinsi Riau Tahun 2016 tercatat 2.951 kasus, Tahun 2017 tercatat 1.114 kasus dan Tahun 2018 kejadian DBD mengalami penurunan menjadi 1.415 kasus. Meskipun kasus DBD mengalami penurunan akan tetapi jumlah kejadian masih cukup tinggi (Profil Dinas Kesehatan Provinsi Riau, 2018).

Berdasarkan data yang diperoleh dari Dinas Kesehatan Kabupaten Kuantan Singingi diketahui kasus DBD mengalami peningkatan setiap tahunnya. Hal ini dapat dilihat dari hasil pencetatan 


\section{SEHATI}

Jurnal Kesehatan
Vol 1, No 2, Agustus 2021, p. 57-62

e-ISSN : 2775-6963 | p-ISSN : 2775-6955

DOI: https://doi.org/10.52364/sehati.v1i2.9

rekapitulasi penyakit DBD pada Tahun 2017 tercatat 98 kasus, Tahun 2018 menjadi 118 kasus dan Tahun 2019 meningkat menjadi 254 kasus.

Menurut data dari Dinas Kesehatan Kabupaten Kuantan Singingi daerah Kecamatan Benai merupakan daerah endemis Demam Berdarah. Sedangkan menurut data dari Badan Pusat Statistik (BPS) Kabupaten Kuantan Singingi, diketahui Tahun 2019 yaitu jumlah penduduk sebanyak 16.525 jiwa dengan jumlah kepala keluarga (rumah tangga) $4.153 \mathrm{KK}$ dengan keadaan pemukiman yang lembab, berada diperkebunan sawit dan rawa-rawa.

Berdasarkan hasil survey yang dilakukan peneliti di Kecamatan Benai terlihat sampah yang tidak dikelola dengan baik, dan terdapat juga tempat-tempat penampungan air bersih yang tidak tertutup, kondisi ini disebabkan karena pengetahuan masyarakat yang kurang tentang pentingnya menjaga kebersihan lingkungan, dan bagaimana cara melakukan $3 \mathrm{M}$. Selain itu adanya sikap masyarakat yang kurang peduli juga menggambarkan bahwa perilaku masyarakat di daerah tersebut masih kurang. Berdasarkan jumlah kejadian DBD di Kecamatan Benai Tahun 2017 tercatat sebanyak 14 orang positif, Tahun 2018 kejadian DBD tercatat sebanyak 17 orang positif, sedangkan Tahun 2019 meningkat tajam sebanyak 36 orang positif mengalami DBD.

\section{METODE PENELITIAN}

Penelitian ini dilaksanakan di Kecamatan Benai Kabupaten Kuantan Singingi, dan menetapkan 3 Desa untuk dilakukan penelitin yaitu Desa Banjar Benai, Desa Benai dan Desa Tebing Tinggi, peneliti memilih 3 Desa ini karena jumlah penderita DBD diwilayah tersebut lebih banyak dibandingkan dengan Desa lainnya.

Jenis penelitian ini adalah analitik kuantitatif dengan desain cross sectional. Jenis data dalam penelitian ini menggunakan data primer yaitu pengumpulan data langsung melalui responden yang diteliti dan melakukan pengambilan data dengan melakukan observasi sanitasi lingkungan dan menyebarkan kuesioner sebagai alat pengumpulan data yang sudah dilakukan.

Populasi dalam penelitian ini adalah seluruh kepala keluarga di Kecamatan Benai yang berjumlah 211 orang, sampel diambil dengan menggunakan metode purposive sampling. Analisa data yang digunakan dalam penelitian ini adalah univariat, bivariat dan multivariat.

\section{HASIL DAN PEMBAHASAN}

\section{Analisis Univariat}

Berdasarkan hasil analisis univariat mengenai frekuensi kejadian DBD, sanitasi lingkungan, ekonomi dan perilaku dapat dilihat pada tabel berikut :

Tabel 1. Distribusi Frekuensi Responden Berdasarkan Univarat Responden di Kecamatan Benai Kabupaten Kuantan Singingi

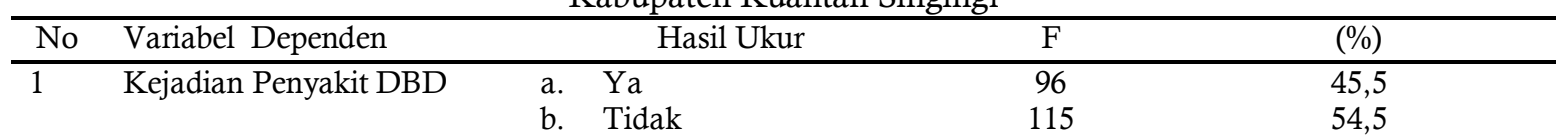

Variabel Independen

2. Sanitasi lingkungan
a. Pengolahan sampah
a. Tidak memenuhi syarat
113
98
a. Tempat penampungan
b. Memenuhi syarat
131 air
a. Tidak memenuhi syarat
80
53,6
b. Memenuhi syarat
46,4
62,1
37,9

$3 \quad$ Ekonomi

a. Rendah

127

60,2

$4 \quad$ Perilaku

b. Tinggi

84

39,8

b. Pengetahuan

a. Kurang

60,7

c. Sikap

b. Baik

a. Kurang

d. Tindakan

b. Baik

39,3

66,8

33,3

a. Kurang $109 \quad 51,7$

e. Baik

48,3 
Berdasarkan Tabel 1 diketahui, dari 211 responden yang diteliti, responden yang mengalami kejadian DBD sebanyak 45,5\%. Untuk variabel pengelolahaan sampah didapatkan sebanyak 53,6\% yang tidak memenuhi syarat. Untuk variabel tempat penampungan air didapatkan hasil sebanyak $62,1 \%$ tidak memenuhi syarat, untuk status ekonomi didapatkan hasil sebanyak $60,2 \%$ dengan status ekonomi rendah, untuk pengetahuan sebanyak $60,7 \%$ responden berpengetahuan kurang, responden yang besikap kurang sebanyak 66,8 dan responden tindakan $3 \mathrm{M}$ dalam kategori buruk sebanyak 51,7\%.

Menurut teori Nazri, Hashim, Rodziah, Hassan, \& Yazid, (2013), yang mengatakan bahwa Demam Berdarah Dengue masih menjadi permasalahan kesehatan baik di wilayah perkotaan maupun wilayah semi-perkotaan. Perilaku vektor dan hubungannya dengan lingkungan, seperti iklim, pengendalian vektor, urbanisasi, dan lain sebagainya mempengaruhi terjadinya wabah demam berdarah di daerah perkotaan. Belum ada prediksi yang tepat untuk menunjukkan kehadiran dan kepadatan vektor (terutama Aedes Aegypti di lingkungan perkotaan dan semi perkotaan).

Menurut asumsi peneliti kejadian DBD masih cukup tinggi di Kecamatan Benai. Kondisi ini disebabkan oleh sanitasi lingkungan yang tidak memenuhi syarat. Hal ini sesuai kondisi sanitasi di lingkungan sekitar rumah warga masih buruk. Masyarakat kurang memperhatikan kebersihan lingkungan sekitar, terutama di daerah pedesaan. Banyak tempat yang ditemukan di sekitar rumah responden yang memiliki kebersihan dan perawatan kurang baik. Kondisi tesebut diantaranya terdapat semak-semak yang tidak dipotong dan dibersihkan, terdapat beberapa tempat yang ditumpuki oleh sampah, banyak tanah lapang yang digunakan untuk menumpuk sampah, banyak kandang-kandang hewan peliharaan (ayam, sapi dan kambing) di belakang rumah yang tidak dirawat dengan baik dan terdapat beberapa tempat makan (warung) yang memiliki pembuangan air limbah kurang baik. Buruknya kondisi sanitasi lingkungan tersebut berpotensi menjadi tempat feeding habbit, resting habbit, dan breeding habbit nyamuk demam berdarah.

\section{Analisis Bivarat}

Berdasarkan hasil analisis bivariat mengenai frekuensi kejadian DBD, sanitasi lingkungan, ekonomi dan perilaku dapat dilihat pada tabel berikut :

Tabel 2. Distribusi Frekuensi Responden Berdasarkan

Bivariat Responden di Kecamatan Benai Kabupaten Kuantan Singingi

\begin{tabular}{cccc}
\hline Variabel penelitian & $\begin{array}{c}\text { Value } \\
\text { (x.hitung) }\end{array}$ & Sig. & Keterangan \\
\hline Sanitasi lingkungan & & & \\
(X1) & & & \\
$\begin{array}{c}\text { Pengolahan Sampah } \\
\text { Tempat }\end{array}$ & 5.026 & .025 & Signifikan \\
$\begin{array}{c}\text { Penampungan Air } \\
\text { Ekonomi (X2) }\end{array}$ & 20.521 & .000 & Signifikan \\
& & & \\
Ekonomi & .235 & .628 & Signifikan \\
& & & \\
& Perilaku (X3) & & \\
Pengetahuan & 26.714 & .000 & Signifikan \\
Sikap & 6.008 & .014 & Signifikan \\
Tindakan & 9.106 & .003 & Signifikan \\
\hline
\end{tabular}

Berdasarkan Tabel 2 diketahui pada uji chi square dari enam subvariabel yang diteliti secara individual terhadap kejadian DBD, variabel pengolahan sampah, tempat penampungan air berpengaruh, suhu dan curah hujan terhadap kejadian DBD didapatkan nilai sig t lebih kecil dari alpha $(0,05)$ yang berarti subvariabel tersebut mempengaruhi kejadian $\mathrm{DBD}$, sedangkan variabel ekonomi didapatkan nilai sig t lebih besar dari alpha $(0,05)$ yang berarti sub variabel tersebut tidak mempengaruhi kejadian DBD.

Hasil penelitian ini sejalan dengan penelitian sebelumnya yang dilakukan oleh Yuka (2011), dengan judul Hubungan PHBS Lingkungan Dengan Kejadian DBD Kecamatan Buleleng, dengan hasil penelitian diperoleh bahwa terdapat hubungan antara pengeloaan sampah dengan kejadian DBD dengan nilai $\mathrm{p}=$ $0,003<0,05$. Sedangkan penelitian Mubarokah (2013), didapatkan hasil penelitian diperoleh bahwa terdapat hubungan antara pengeloaan sampah dengan kejadian DBD dengan nilai $p=0,041<0,05$. 


\section{SEHATI}

Jurnal Kesehatan
Vol 1, No 2, Agustus 2021, p. 57-62

e-ISSN : 2775-6963 | p-ISSN : 2775-6955

DOI: https://doi.org/10.52364/sehati.v1i2.9

Berdasarkan hasil penelitian dan teori diatas, peneliti menyimpulkan adanya pengaruh antara sanitasi lingkungan, yang dapat dilihat dari pengelolaan sampah ditempat tinggal mereka terlihat sangat buruk, dari kenyataan dilapangan dapat dilihat banyak masyarakat yang membuang sampah pada tempat sampah galian yang tidak tertutup, selain itu banyak juga masyarakat yang menyimpan barang-barang bekas seperti kaleng, ember bekas dan lainnya yang dapat menampung air hujan, sampah tersebut tidak pernah dikurbur, sedangkan sampah yang terdapat pada lobang sampah juga tidak pernah ditimbun walau sampah sudah penuh, kondisi mengakibatkan nyamuk aedes aegypti mudah untuk bersarang ditempat sampah tersebut dan masyarakat yang tinggal disekitarnya berisiko mengalami kejadian DBD.

Menurut asumsi peneliti tentang tempat penampungan air ditempat tinggal mereka terlihat sangat buruk, dari kenyataan dilapangan dapat dilihat banyak masyarakat yang menggunakan tempat penampungan air seperti drum, tempayan, ember dan lainnya, selain itu tempat penampungan air tersebut terlihat dalam kondisi terbuka, hal mengakibatkan nyamuk aedes aegypti mudah untuk bertelur dan bersarang ditempat penampungan air tersebut. Tempat penampungan air yang berisiko terhadap kejadian DBD didefinisikan sebagai tempat penampungan air yang memungkinkan sebagai habitat perkembangbiakan Aedes aegypti. Sedangkan tempat penampungan air berisiko adalah wadah air minum yang terbuka (tanpa tutup) sedangkan yang tidak berisiko yang wadahnya tertutup. Jika dikaitkan dengan vektor DBD hal tersebut akan menunjukkan hasil yang berbeda, karena kondisi TPAM air bersih yang terbuka akan memberikan peluang yang besar bagi nyamuk Aedes untuk berkembang biak, sehingga dikhawatirkan dengan tersedianya tempat perkembangbiakan nyamuk DBD akan memperbesar kemungkinan nyamuk tersebut menularkan penyakit DBD. Namun tenyata dalam analisis data Riskesdas ini tidak terbukti, hal tersebut mudah dimengerti jika TPAM terbuka tersebut sering dikuras dan disikat minimal 1 minggu sekali sehingga nyamuk tidak dapat berkembang biak. Perlu ditambahkan, bahwa pengakuan responden yang menyatakan menutup TPAM namun sebagian diantaranya temyata masih terbuka sehingga nyamuk masih dapat bertelur didalamnya.

\section{Analisis Multivariat}

Analisa multivariat dalam penelitian menggunakan Regresi logistik biner yang merupakan suatu metode analisis data yang digunakan untuk mencari hubungan antara variabel respon (y) yang bersifat biner atau dikotomus dengan variabel prediktor $(\mathrm{x})$ yang bersifat politokomus. Berikut adalah hasil analisis regresi logistik biner untuk mengetahui Pengaruh Sanitasi Lingkungan dan Perilaku Keluarga Terhadap Kejadian Penyakit Demam Berdarah Dengue (DBD) di Kecamatan Benai Kabupaten Kuantan Singingi.

\section{Hasil Uji Signifikansi Parameter secara Serentak}

Tabel 3. Hasil Uji Signifikansi Parameter Secara Serentak

\begin{tabular}{llccc}
\hline & & Chi-square & Df & Sig. \\
\hline Step 1 & Step & 36.592 & 3 & .000 \\
& Block & 36.592 & 3 & .000 \\
& Model & 36.592 & 3 & .000 \\
\hline
\end{tabular}

Berdasarkan Tabel 3 diketahui pada uji Signifikansi Parameter Secara Serempak diketahui nilai signifikasi diperoleh $0,000<0,05$, yang berarti terdapat satu variabel yang berpengaruh signifikan.

\section{Hasil Uji Signifikansi Parameter Secara Parsial}

Tabel 4. Hasil Uji Signifikansi Parameter Secara Parsial

\begin{tabular}{lcccc}
\hline $\begin{array}{c}\text { Variabel } \\
\text { penelitian }\end{array}$ & $\mathrm{B}$ & Wald & Df & $\begin{array}{c}\text { P- } \\
\text { Value }\end{array}$ \\
\hline Sanitasi & 1.366 & 5.708 & 1 & .017 \\
lingkunga & & & & \\
$\mathrm{n}$ & & & & \\
Ekonomi & .082 & .067 & 1 & .795 \\
Perilaku & -2.753 & 21.44 & 1 & .000 \\
& & 2 & & \\
Constant & 1.366 & 5.708 & 1 & .017 \\
\hline
\end{tabular}

Berdasarkan Tabel 4 diketahui pada Uji Signifikansi Parameter Secara Parsial diketahui nilai signifikasi untuk sanitasi lingkungan dan perilaku $<$ alpha $(0,05)$, sedangkan untuk variabel ekonomi nilai 


\section{SEHATI}

Jurnal Kesehatan
Vol 1, No 2, Agustus 2021, p. 57-62

e-ISSN : 2775-6963 | p-ISSN : 2775-6955

DOI: https://doi.org/10.52364/sehati.v1i2.9

signifikasi $>$ alpha $(0,05)$. Dari hasil tersebut dapat disimpulkan bahwa variabel sanitasi lingkungan dan perilaku mempengaruhi kejadian DBD.

Penelitian ini sejalan dengan penelitian Sucina (2016), bahwa sanitasi lingkungan dan perilaku mempengaruhi kejadian DBD. Menurut penelitian Yuka (2011), dengan judul Hubungan PHBS Lingkungan Dengan Kejadian DBD Kecamatan Buleleng, dengan hasil penelitian diperoleh bahwa terdapat hubungan antara tempat penampungan air dengan kejadian DBD dengan nilai $\mathrm{p}=0,002<0,05$. Selain itu menurut Mubarokah (2013), didapatkan hasil penelitian diperoleh bahwa terdapat hubungan antara TPA dengan kejadian DBD dengan nilai $\mathrm{p}=0,010<0,05$.

\section{Hasil Uji Kesesuaian Model}

Berdasarkan uji kesesuaian model diketahui nilai $X_{\text {hitung }}(0,417)$ kurang dari $X_{\text {hitung }}(15,507)$. Sedangkan nilai pvalue $(0,925>0,05$, sehingga dapat diputuskan bahwa model sesuai artinya tidak terdapat perbedaan yang signifikan antara hasil pengamatan dengan kemungkinan hasil prediksi model. Kebaikan model yang didapatkan dalam analisis digunakan untuk mengetahui sejauh mana variabel prediktor dapat menjelaskan model yang terbentuk dengan melihat nilai $R$ - $s q$ yaitu sebesar 0,213 , hal ini menunjukkan bahwa nilai Nagelkerke $R-S q$ sebesar 21,3\% yang berarti model dapat dijelaskan oleh variabel prediktor sebesar $21,3 \%$.

\section{Hasil Odds ratio (OR)}

Tabel 5. Nilai Odds Ratio

\begin{tabular}{lc}
\hline \multicolumn{1}{c}{ Estimasi Parameter } & Odds Ratio \\
\hline Sanitasi lingkungan (X1) & 3,919 \\
Ekonomi (X2) & 1,085 \\
Perilaku (X3) &, 064 \\
\hline
\end{tabular}

Tabel 5 menunjukkan bahwa nilai Odds ratio dari sanitasi lingkungan lebih dari 1, sehingga sanitasi lingkungan cenderung mempunyai resiko paling tinggi terhadap kejadian DBD.

Hasil ini sejalan dengan penelitian yang dilakukan oleh Muchlis, dkk (2013), yang menunjukkan bahwa OR = 2,208; 95\% CI =0,705-6,921 yang berarti bahwa sanitasi lingkungan merupakan faktor risiko tinggi terhadap kejadian DBD. Menurut penelitian Mada (2013). dengan nilai OR= 2,781 yang berarti sanitasi lingkungan yang buruk 3 kali berisiko mengalami kejadian DBD.

\section{Hasil Uji Ketepatan Klasifikasi Model}

Tabel 6. Ketepatan Klasifikasi Model

\begin{tabular}{|c|c|c|c|}
\hline \multirow[t]{2}{*}{$\mathrm{Y}$} & \multicolumn{2}{|c|}{$\begin{array}{c}\text { Predi } \\
\text { ksi }\end{array}$} & \multirow[t]{2}{*}{ Total } \\
\hline & $\mathrm{Ya}$ & Tidak & \\
\hline $\mathrm{Ya}$ & 77 & 19 & 80.2 \\
\hline Tidak & 51 & 64 & 55.7 \\
\hline Total & 128 & 83 & 66.8 \\
\hline
\end{tabular}

Tabel 6 menunjukkan bahwa sanitasi lingkungan dan perilaku diklasifikasikan sebesar 128 responden mengalami DBD, sedangkan sebesar 83 pasien tidak mengalami DBD. Model dapat mengklasifikasikan secara tepat $66,8 \%$.

Tabel 6 menunjukkan bahwa sanitasi lingkungan dan perilaku diklasifikasikan sebesar 128 responden mengalami DBD, sedangkan sebesar 83 pasien tidak mengalami DBD. Model dapat mengklasifikasikan secara tepat 66,8\%.

Menurut penelitian yang dilakukan oleh Puspita Sari (2013), bahwa ada hubungan antara sanitasi lingkungan, perilaku dan praktik PSN dengan kejadian DBD pada sekolah tingkat dasar di Kota Semarang $(p$ value $=0,05)$. Makin tinggi pengetahuan, sikap dan tindakan ibu, makin baik perilaku pencegahan DBD dan semakin kecil risiko terjadinya DBD.

Menurut asumsi peneliti, kejadian DBD di Kecamatan Benai diindikasikan menyebar karena buruknya sanitasi tempat umum. Hal tersebut didukung beberapa pernyataan responden yang menyebutkan bahwa responden tergigit nyamuk sebelum menderita DBD di tempat-tempat umum diantaranya adalah pasar, warung, kebun, dan lingkungan lainnya. Kondisi ini sesuai dengan teori bahwa salah satu pusat penularan DBD adalah tempat umum. Tempat-tempat umum merupakan tempat berkumpulnya orang-orang yang datang dari berbagai wilayah, sehingga kemungkinan terjadinya pertukaran beberapa tipe virus dengue cukup besar. Pengendalian jentik dan nyamuk merupakan perilaku 


\section{SEHATI}

Jurnal Kesehatan
Vol 1, No 2, Agustus 2021, p. 57-62 e-ISSN : 2775-6963 | p-ISSN : 2775-6955 DOI: https://doi.org/10.52364/sehati.v1i2.9

yang dilakukan untuk mencegah, mengontrol, dan menghilangkan jentik dan nyamuk melalui berbagai metode (termasuk $3 \mathrm{M}$ plus). Selain itu, pencapaian PJN (pengendalian jentik dan nyamuk) berimplikasi pada pencapaian ABJ. Rendahnya pencapaian tersebut sejalan dengan data Dinas Kesehatan Kabupaten Kuantan Singingi dalam pencapaian Angka Bebas Jentik (ABJ) di wilayah penelitian pada bulan Maret hingga April 2020 yang kurang memuaskan.

Pencapaian ABJ belum mencapai target harapan ABJ sebesar 95\%. Kondisi ini diakibatkan karena kurangnya edukasi kepada masyarakat tentang perilaku pemberantasan nyamuk yang lebih kompleks. Selama ini masyarakat hanya diberikan informasi tentang 3M. Padahal untuk mengurangi kejadian DBD perlu ada pengendalian yang lebih kompleks baik pengendalian jentik maupun nyamuk, seperti pengendalian pada tempat istirahatnya dan pengendalian terhadap pola aktivitasnya, sehingga $3 \mathrm{M}$ saja tidak cukup. Karena itu diperlukan diperlukan edukasi yang baik dan kompleks agar masyarakat dapat meningkatkan keikutsertaannya dalam mengontrol keberadaan jentik dan nyamuk. Sesuai dengan arahan WHO bahwa pendidikan kesehatan sangat penting dalam keberhasilan pastisipasi komunitas. Hal tersebut merupakan proses jangka panjang yang akan merubah perilaku manusia dan akan menjadi dasar yang kuat dan kontinyu. Jika negara tidak memiliki sumber daya manusia yang cukup, maka yang diutamakan adalah daerah yang endemik dan memiliki faktor resiko tinggi terkena DBD. Pada prinsipnya jika PJN buruk maka dapat meningkatkan terjadinya penularan DBD.

\section{KESIMPULAN}

Kondisi faktor sanitasi lingkungan, ekonomi dan perilaku di Kecamatan Benai Kabupaten Kuantan Singingi belum optimal sehingga berisiko mengalami kejadian DBD, sehingga terdapat pengaruh sanitasi lingkungan terhadap kejadian penyakit Demam Berdarah Dengue (DBD) di Kecamatan Benai Kabupaten Kuantan Singingi, tidak terdapat pengaruh ekonomi terhadap kejadian penyakit Demam Berdarah Dengue (DBD) di Kecamatan Benai Kabupaten Kuantan Singingi, dan terdapat pengaruh perilaku keluarga terhadap kejadian penyakit Demam Berdarah Dengue (DBD) di Kecamatan Benai Kabupaten Kuantan Singingi.

\section{UCAPAN TERIMAKASIH}

Terimakasih kepada kedua pembimbing saya yang telah banyak membantu dalam menyelesaikan penelitian ini, juga kepada kedua orang tua saya yang telah mengizinkan saya menyelesaikan studi saya, serta teman-teman seperjuangan yang tidak dapat saya sebutkan satu persatu, dan juga kepada seluruh pihak yang terlibat di Kecamatan Benai yang telah mengizinkan saya melakukan penelitian ini.

\section{DAFTAR PUSTAKA}

Depkes, RI. (2013). Panduan Penanganan DBD. www.http.jurnal.kesehatan.pdf.vol3421. Accessed on juni. 12,2020

Dinas Kesehatan Provinsi Riau. (2018). Profil Dinas Kesehatan Provinsi Riau. Pekanbaru

Nazri, CD., Hashim, A., Rodziah, I., Hassan, A., \& Yazid, AA. (2013). Utilization of Geoinformation Tools for Dengue Control Management Strategy: A Case Study in Seberang Prai, Penang Malaysia. International Journal of Remote Sensing Applications. 2013;11-17

Mubarokah. (2013). Upaya Peningkatan Angka Bebas Jentik Demam Berdarah Dengue Melalui Pergerakan Juru Pemantau Jentik Di RW I Kelurahan Dayang Kecamatan Purwodadi Kabupaten Geronggongan. www.http.jurnal.kesehatan.pdf.vol3421. Accessed on juni. 12, 2020

Muchlis, S., Ishak, H., \& Ibrahim, E. (2013). Faktor Resiko Upaya Menghindari Gigitan Nyamuk Terhadap Kejadian DBD di Puskesmas Patingalloang Makasar. Repository Unhas. Available From: Repository.unhas.ac.id

Sari, P. (2012). Hubungan kepadatan jentik Aedes sp dan praktik PSN dengan kejadian DBD di sekolah dasar di Kota Semarang. Jurnal Kesehatan Masyarakat, 1(1): 413-422

World Health Organization. (2009). Demam Berdarah Dengue. Jakarta. ECG

Yuka. (2011). Hubungan PHBS Lingkungan Dengan Kejadian DBD di Kecamatan Buleleng.www.http.jurnal.kesehatan.pdf.vol3421. accessed on juni. 12, 2020 